\title{
5 - KOG Test Performance on Patients with Schizophrenia, Alcoholism and Depression
}

\author{
Ivana Križanac ${ }^{1}, K^{\prime}$ runoslav Matešić ${ }^{1}$, Dalibor Karlović ${ }^{1,}{ }^{2}$ \\ ${ }^{1}$ Catholic University of Croatia, Zagreb, Croatia, ${ }^{2}$ Department of Psychiatry, \\ University Hospital Center Sestre milosrdnice, Zagreb, Croatia,
}

\begin{abstract}
Cognitive functions are essential for the normal functioning of every individual,and in cases when they are damaged we speak of cognitive deficits. Each psychiatric disorder is specific to the area and extent of cognitive deficits, and their detection is of great importance for differential diagnosis, treatment success, rehabilitation as well as social reintegration of patients. This study compared the performance on the 5-KOG test, ie investigated differences in performance on subtests of short-term and long-term memory, attention and speed of information processing, working memory, verbal fluency, and executive functions, in clinical groups of schizophrenia, alcoholism, and depression. The correlations between the subtests for each clinical group were also analyzed. A total of 86 participants, who were treated at a psychiatric clinic in a hospital in the city of Zagreb during this research, participated in the study, out of which 29 belonged to the schizophrenia group, 28 belonged to depression group and 29 belonged to the clinical group of alcoholism. A 5-KOG triage test was used to assess cognitive function in psychiatric disorders. Results showed no significant difference in the performance on subtests of undelayed and delayed recall, attention and speed of information processing, working memory, verbal fluency, and executive functions, among the studied clinical groups.
\end{abstract}

Keywords: schizophrenia, alcoholism, depression, cognitive functions

Copyright @ 2020 KBCSM, Zagreb

e-mail: alcoholism.kbcsm@gmail.com•www.http://apr.kbcsm.hr

\section{Introduction}

Each one of us is involved in a large number of actions that define us daily, although we are sometimes unaware of it: we participate in discussions, make our own opinions, focus on essential activities, we plan, find ways to solve the problem, use our old

Correspondence to:

Ivana Križanac

Catholic University of Croatia, Ilica 242, Zagreb, Croatia

e-mail:ivana.krizanac1@unicath.hr skills and acquire new ones. What enables us to function daily on a personal, social and professional level is cognition [1]. Cognition includes various cognitive functions - intellectual processes by which we become aware of something, perceive and understand ideas, that is, by which we receive and process information [2]. Although cognitive functions are crucial for the normal functioning of each individual, they are subject to impairment.In this case, we talk about cognitive deficits that Akrap and associates [3] define 
as "temporary or permanent disruption of mental abilities, starting from the lower level of informationprocessing (attention, perception) to the most complex intellectual functions (abstract thinking, memory, and general intelligence)". Discovering deficits in psychiatric disorders plays an important role in the differential diagnosis, treatment success, rehabilitation as well as social reintegration of patients, which is why it is extremely important to identify specific deficits in certain cognitive areas among patients with various psychiatric diagnoses [4]. It is precisely this topic addressed in the study, which compared the cognitive performance of three major psychiatric disorders: schizophrenia, alcoholism, and depression.

\section{Schizophrenia}

Given that the focus of schizophrenia research was blurred for a long time, it is not surprising that until the early 90s of the last century it was commonly believed that schizophrenic patients had very little cognitive impairment and that they were classified as secondary symptoms [5]. However, there was a sudden shift in the research paradigm, so the number of studies that have examined cognitive deficits in schizophrenia grew rapidly. Over time, the importance of cognitive deficits has become increasingly clear, and today it is considered that cognitive deficits are a basic feature of schizophrenia [6].

One of the most damaged cognitive functions is the speed of information processing, which is not surprising given that psychomotor slowing is easily noticeable in clinical practice [7]. Thus meta-analysis by Dickinson and associates [8] shows the most difficult and most significant damage in that domain. According to these findings, a meta-analysis by Schaefer and associates [9] highlights the speed of information processing as the most deficient, as well as the meta-analysis by Rajji and associates [6]. Though it has long been considered that executive function deficits are the result of acute disorganization resulting from psychotic episodes, it is increasingly accepted opinion that it is a core component of schizophrenia [10]. Thus, the results of research by Bryson and associates [11] have shown that schizophrenic patients achieve significantly worse results in executive function tests compared to the general population, and most of the later studies $[10,12,13]$ confirmed these findings.

\section{Alcoholism}

Despite the fact that the direct effect of alcoholism on cognitive functioning was first noticed in the late 19th century, the real interest in research of cognitive deficits underlying alcoholism attracted only three decades ago when there was a sudden increase in research in this area [14]. Although today is well-known that chronic drinking leads to a wide range of cognitive impairment, the results of the research are rather inconsistent with what functions are impaired.

The results of previous studies have proved to be inconsistent for all cognitive functions except for executive functions. Thus, for example, Pitel and associates [15] estimated executive functions using organization, inhibition, flexibility, updating and integration tests, and alcoholics showed deficits in all of these tasks. Interestingly, the meta-analysis results of Stavro and associates took into account an abstinence period, distinguishing short-term abstinence of fewer than 31 days, intermediate abstinence of 32 days to 365 days, and long-term abstinence 
longer than 365 days [16]. Significant executive function deficits have been found in all alcohol-dependent patients, regardless of the period of abstinence.

\section{Depression}

Although depressive disorder was primarily characterized as a mood disorder, studies have shown that is associated with significant deficits of cognitive functioning [17]. Studies show that depressive patients have difficulties in the way they process, interpret and store information [18], and it is estimated that these deficits occur with as many as two thirds of the patients, as well as that between one third and one half of the patients show difficulties in remission [19]. However, although it is widely accepted that depression is associated with cognitive deficits, there is still disagreement over the most affected areas [20].

Once again, results have shown inconsistency for all cognitive functions except for the attention and speed processing. People suffering from depression often complain of a lack of concentration that affects their daily life. Patients thus point to difficulties in performing several activities one after another, ignoring distractors or even maintaining the conversation [21]. Previous research has confirmed such claims, so Porter and associates [22] state that the largest effect of the research was found in the tests of attention, and Ravnkilde and associates [21] found significant deficits for all the attention tests used. It is not uncommon for depressive patients to point out a subjective feeling of psychomotor slowing. Although psychological tests do not always confirm such allegations, most of such a statement proves to be true. Thus Gohier and associates [23] found that although patients with depression did not make any mistakes in comparison to the control group, they still needed significantly more time to complete the task, while McDermott and associates [24] found a negative correlation between the severity of the disease and the speed processing.

\section{Depression vs. Schizophrenia}

Many studies have compared cognitive functions in schizophrenia, depression, and alcoholism with a healthy control group. However, despite the increasing evidence suggesting neuropsychological dysfunction of patients with these psychiatric disorders, very few studies focused on comparing cognitive functions in these disorders. Such studies are of utmost importance since the comparison would provide an opportunity to determine the difference in degree, profile and specificity of cognitive impairment in each disorder separately [25].

Literature review shows that there are very few such studies and that the subject of such comparisons were only clinical groups of schizophrenia and depression. One of those rare research was Šoštarić's and Zalar's which tested working memory, attention and immediate and delayed recall [4]. Both clinical groups have shown significantly lower results compared to test standards in all tasks, with the exception of a digit span test. More specifically, no significant difference was found for schizophrenic patients compared to the test standards for the forward digit span, nor for the backward digit span. On the other hand, while a significant difference in depressed patients was not found for the forward digit span, it was found for the backward digit span. Another important finding of this study lies in the fact that both clinical groups showed psychomotor slowing, 
which confirmed previous findings that indicate that due to lack of energy in depression and avolition in schizophrenia, psychomotor slowing is not characteristic only for depression, but for both these disorders. Fossati and associates in their study compared the cognitive impairment in schizophrenia, depression and the healthy population, and the results indicate a certain qualitative and quantitative differences between clinical groups [25]. The results showed that schizophrenic and depressive patients produced significantly fewer words on the semantic fluency test, while only schizophrenic patients differed significantly from the control group in the lexical fluency test. On the other hand, even though both clinical groups were significantly worse in comparison to a healthy population in the forward digit span test, only depressive patients achieved significantly lower results compared to a healthy population on the backward digit span test. Also, although in the Card sorting test both clinical groups made more perseverative errors, no significant difference was found compared to the healthy population. On the other hand, the results of Moritz and associates showed that while depressed and schizophrenic patients are significantly worse in comparison to the control group in digit span task, verbal fluency test, and card sorting test, deficits of these cognitive functions are not limited to any of these psychiatric groups [26]. Therefore, the authors consider that the mentioned deficits represent a more general vulnerability that may affect various psychiatric disorders.

The aim of this study was to compare the performance on the 5-KOG test, ie to determine whether there is a difference in performance on the subtests of short-term and long-term memory, attention and speed processing, working memory, verbal fluency, and executive functions, in clinical groups of schizophrenia, alcoholism, and depression.

\section{Subjects and methods}

\section{Subjects}

A total of 86 voluntary patients, who were at the time of research treated in the Psychiatric Clinic in a hospital in Zagreb, participated in the study. Based on their clinical diagnosis, the participants were divided into three groups, so the sample consisted of 29 schizophrenic patients, 28 depressed patients, and 29 alcoholic patients. The study involved 47 men and 39 women aged 19 to 70 , who mostly held high school education.

\section{Methods}

For the purpose of this study, a $5-\mathrm{KOG}$ triage test was used to assess cognitive function in psychiatric disorders [7]. The test consists of 5 subtests examining: 1. short-term and long-term memory, 2. attention and speed processing, 3. working memory, 4. verbal fluency, and 5. executive functions.

In the task of short-term memory, the examiner reads the story to the participant, after which he needed to recall as much detail as possible. For each correct story detail, the participant would get 1 point, out of a total of 11 points. The task of long-term memory requires the participant to recall story details after the participant completes the entire test (15 to 20 minutes), without re-reading the story.The subtest of attention and speed processing required quick symbol coding from the key listed at the top of the task. Each of the six numbers had their own corresponding character (eg number 1 corresponds to the sign -), and the aim was to encode as many numbers as possible in 30 seconds. The sub- 
test of working memory required memorizing a series of numbers that participant needed to repeat in the same order or backward. The verbal fluency subtest is divided into two categories: the first task consisted of naming as many words as possible that belong to the given category, while the second task consisted of naming as many nouns that start with the given letter. Each task was time limited to 30 seconds. The last subtest referred to the executive functions task, and the goal is to sort cards according to one of three possible dimensions. The subject had to determine the correct strategy on the basis of right or wrong feedback presented after the subject's response to each card. Dimensions changed after 8 correct answers in a row, and the test ended either when all cards or dimensions were sorted.

\section{Data collection and statistics}

The study was conducted in accordance with the ethical standards, and all the participants signed the informed consent form. The anonymity of the data was guaranteed, and the results were used only for scientific purposes.Testing was performed individually, and on average it took about 20 minutes per participant.The responses were written by the examiner for all the subtests, except for the subtest of attention and speed processing, in which the subjectwrote the answers by themselves. The research was conducted in the period from June to October 2018. The data collected in this study were processed by statistical package IBM SPSS Statistics, version 20 .

\section{Results}

Descriptive statistics of the investigated variables, ie of short-term and long-term memory, attention and speed processing, working memory, verbal fluency, and executive functions, for the clinical groups of schizophrenia, depression, and alcoholism are presented in Table 1. It is evident that all three clinical groups achieved approximately similar results in all subtests, with the exception of subtest of executive functions, where alcoholics achieved the least correct responses $(\mathrm{M}=19.38, \mathrm{SD}=6.54)$ and made the most errors $(\mathrm{M}=19.48$; $\mathrm{SD}=8.11)$ and perseverative $(\mathrm{M}=13.34 ; \mathrm{SD}=8.67)$ responses, compared to patients suffering from schizophrenia and depression.

To determine the relationship between the subtests of the 5-KOG triage test for the investigated clinical groups, Pearson correlation coefficients were calculated. As seen in Table 2 , a significant positive correlation was found between short-term and long-term memory subtests $(\mathrm{r}=.81, \mathrm{p}<.01)$, attention and speed processing subtest and verbal fluency subtest $(\mathrm{r}=.49, \mathrm{p}<.01)$, attention and speed processing subtest and short-term $(\mathrm{r}=.33, \mathrm{p}<.01)$ as well as long-term memory subtests $(\mathrm{r}=.37$, $\mathrm{p}<.01$ ), verbal fluency subtest and short-term subtest $(\mathrm{r}=.27, \mathrm{p}<.05)$ as well as long-term memory subtest $(\mathrm{r}=.30, \mathrm{p}<.05)$, working and long-term memory subtests $(\mathrm{r}=.23, \mathrm{p}<.05)$ and verbal fluency subtest and working memory subtest $(\mathrm{r}=.25, \mathrm{p}<.05)$. The only significant negative correlation was found between long-term memory subtest and the number of trials in the subtest of executive function $(\mathrm{r}=-.27, \mathrm{p}<.05)$.

In order to determine whether performance on 5-KOG triage test differed among the clinical groups of schizophrenia, alcoholism, and depression, a one-way ANOVA was performed. Table 3 shows that the results did not show a statistically significant difference in any of the tested cognitive function 
Table 1. Descriptive statistics of examined cognitive functions for clinical groups of schizophrenia, alcoholism, and depression.

\begin{tabular}{lcccccc}
\hline & \multicolumn{2}{c}{$\begin{array}{c}\text { Schizophrenia } \\
(\mathrm{N}=29)\end{array}$} & \multicolumn{2}{c}{$\begin{array}{c}\text { Depression } \\
(\mathrm{N}=28)\end{array}$} & \multicolumn{2}{c}{$\begin{array}{c}\text { Alcoholism } \\
(\mathrm{N}=29)\end{array}$} \\
\cline { 2 - 7 } & $\mathrm{M}$ & $\mathrm{SD}$ & $\mathrm{M}$ & $\mathrm{SD}$ & $\mathrm{M}$ & $\mathrm{SD}$ \\
\hline Immediate recall & 4.93 & 1.94 & 4.46 & 1.84 & 4.86 & 1.77 \\
Delayed recall & 4.48 & 2.21 & 4.04 & 1.73 & 4.28 & 1.96 \\
$\begin{array}{l}\text { Attention and speed of } \\
\text { information processing }\end{array}$ & 13.21 & 3.80 & 11.89 & 4.23 & 12.79 & 3.48 \\
Working memory & 8.07 & 1.91 & 7.25 & 1.86 & 7.55 & 1.66 \\
Verbal fluency & 14.66 & 3.43 & 14.96 & 3.63 & 14.52 & 3.74 \\
Number of correct answers & 21.97 & 4.90 & 21.86 & 5.84 & 19.38 & 6.54 \\
Number of incorrect answers & 16.31 & 7.01 & 16.43 & 7.36 & 19.48 & 8.11 \\
Number of perseverative errors & 9.52 & 6.43 & 10.79 & 8.00 & 13.34 & 8.67 \\
Number of trials & 38.28 & 3.92 & 38.29 & 3.05 & 38.93 & 2.43 \\
The percentage of correct & 0.59 & 0.16 & 0.58 & 0.17 & 0.51 & 0.19 \\
answers & & & & & & \\
The percentage of incorrect & 0.24 & 0.16 & 0.28 & 0.20 & 0.33 & 0.21 \\
answers & & & & & & \\
The percentage of perseverative & 0.17 & 0.15 & 0.14 & 0.17 & 0.16 & 0.09 \\
errors & 1.66 & 0.81 & 1.82 & 1.02 & 1.72 & 0.84 \\
Number of completed series & & & & & & \\
\hline
\end{tabular}

with respect to the clinical diagnosis. Specifically, there was no significant difference in performance on subtests of short-term and long-term memory, attention and speed processing, working memory, verbal fluency, and executive functions between clinical groups of schizophrenia, depression, and alcoholism.

\section{Discussion}

The first aim of this study was to investigate the existence of a significant correlation between subtests of the 5-KOG triage test.
Given that this test was not used in previous research, we were unable to predict the existence of statistically significant correlations between subtests.

The highest coefficient of correlation was found between short-term and longterm memory subtests. Given the nature of mentioned subtests, where the respondents repeat the story read right before for short-term memory and with time delay for long-term memory, we can conclude that such results are not surprising. A moderate correlation was found between verbal flu- 


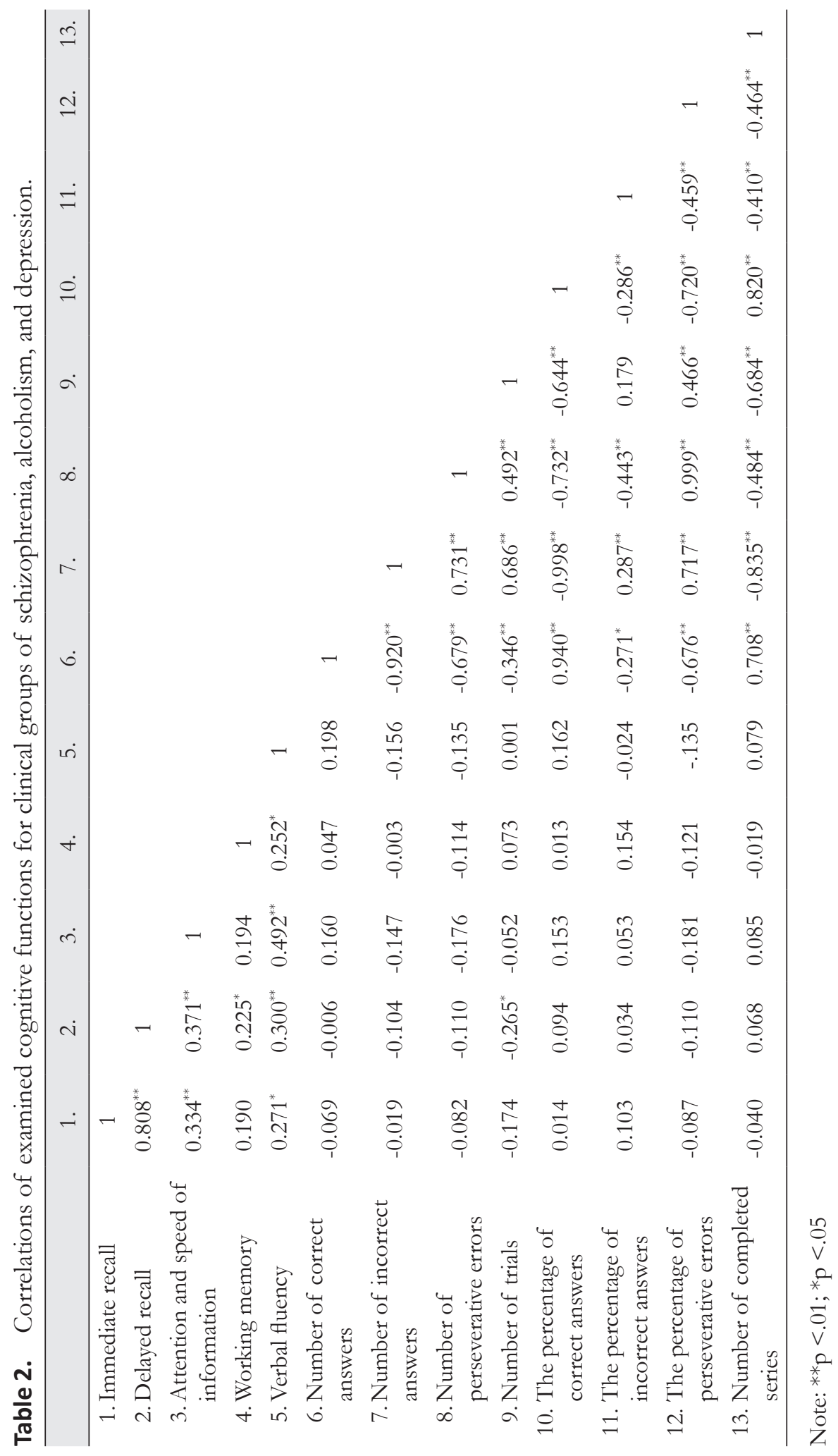


Table 3. Differences in performance on the 5 - KOG test with regard to diagnosis of schizophrenia, depression and alcoholism.

\begin{tabular}{lrrrc}
\hline & & Sum of & & Sig. \\
& df & Squares & \multicolumn{1}{c}{ F } & 0.593 \\
Immediate recall & 2 & 3.597 & 0.525 & 0.697 \\
Delayed recall & 2 & 2.850 & 0.363 & 0.424 \\
Attention and speed of information processing & 2 & 25.630 & 0.867 & 0.230 \\
Working memory & 2 & 9.809 & 1.495 & 0.892 \\
Verbal fluency & 2 & 2.975 & 0.115 & 0.166 \\
Number of correct answers & 2 & 123.488 & 1.836 & 0.197 \\
Number of incorrect answers & 2 & 186.625 & 1.655 & 0.167 \\
Number of perseverative errors & 2 & 220.295 & 1.830 & 0.673 \\
Number of trials & 2 & 8.131 & 0.398 & 0.176 \\
The percentage of correct answers & 2 & 0.112 & 1.775 & 0.718 \\
The percentage of incorrect answers & 2 & 0.013 & 0.333 & 0.164 \\
The percentage of perseverative errors & 2 & 0.135 & 1.847 & 0.781 \\
Number of completed series & 2 & 0.397 & 0.248 & \\
\hline
\end{tabular}

ency subtest and attention and information processing speed subtest. Given that among the main symptoms of the examined disorders are disturbances of thought, speech, and concentration, it seems that patients needed a greater amount of attention and information processing in order to generate words for subtest of verbal fluency. Another correlation was found between the results on the attention and information processing speed subtest and short-term and long-term memory subtests. These findings seem logical given the fact that attention and information processing speed are key for memorizing as many details from the story, as well as for retrieving them after a time delay. Correlation was also found between verbal fluency subtest and short-term and long-term memory subtests. Given that the task of fluency from respondents requires access to their mental lexicon, ie words stored in long-term memory and retrieves them to short-term memory to generate them for the task, we can conclude that such correlation was expected. However, if we conclude that systems of verbal fluency use systems of short and long-term memory, it is expected that correlation will be stronger. It seems that the symptoms of the examined disorders, such as disturbances of thinking and concentration, have once again influenced the results. The negative correlation coefficient was found between the number of trials and long-term memory subtest. What has potentially affected this result is the fact that it is necessary to organize and use learned knowledge for solving executive functions subtest, so people who have better long-term memory memorizes the rules of the task at hand, earlier on. Another correlation was found between working memory 
subtest and verbal fluency subtest. Such correlation could be explained by the fact that in order to successfully generate words for subtest of verbal fluency, the manipulation of knowledge stored in the mental lexicon is needed, and it is precisely the element of manipulation with the learned content that is the main feature of the working memory. The last correlation was found between working and long-term memory subtests. This kind of correlation is not surprising given that the working memory uses long-term memory systems to retrieve learned knowledge, as well as it helps retain information long enough to store it.

\section{Differences in performance}

Despite the growing number of studies pointing to similar cognitive deficits in schizophrenia, alcoholism, and depression, no research has compared the cognitive function between these disorders. Given this condition, we weren't able to predict the existence of statistically significant differences in the performance of the $5-\mathrm{KOG}$ test among the studied clinical groups.

Our research did not find a statistically significant difference in performance on subtests of short-term and long-term memory, attention and speed of information processing, working memory, verbal fluency and executive functions among clinical groups of

\section{References}

1. Sharma T, Antonova L. Cognitive function in schizophrenia: Deficits, functional consequences, and future treatment. Psychiatr Clin North Am. 2003;26:25-40. schizophrenia, depression, and alcoholism. These findings are partially in line with the research of Šoštarić and Zalar and Moritz and associates which compared the cognitive function in schizophrenia and depression and who have not found statistically significant differences in any domain other than working memory, that was significantly worse in depression patients in the first study $[4,26]$. Although we can not speak in deficit terms, Moritz and associates argue that this lack of distinction between groups suggests that the observed difficulties are more general than the specific vulnerability to psychiatric illness [26]. On the other hand, such results can be partially attributed to the instrument used. Namely, it is a triage test whose tasks are not sufficiently thorough and extensive, therefore it is possible that using some other instrument for testing cognitive functions would yield different results. Also, it would be useful to include a group from the general population, because comparation of these results would give us a better understanding of the impairments in schizophrenia, depression and alcoholism.

\section{Acknowledgements}

None.

\section{Conflicts of interest}

None to declare. 
3. Akrap L, Jakšić N. The role of neurocognitive deficits in schizophrenia - studies and clinical practice. Soc psihijat. 2016;44:3-13.

4. Šoštarič M, Zalar B. The overlap of cognitive impairment in depression and schizophrenia: a comparative study. Psychiat Danub. 2011;23:251-6.

5. Reichenberg A, Harvey PD. Neuropsychological impairments in schizophrenia: Integration of performance-based and brain imaging findings. Psychol Bull. 2007;133:833-58.

6. Rajji TK, Miranda D, Mulsant BH. Cognition, function, and disability in patients with schizophrenia: a review of longitudinal studies. Can J Psychiatry. 2014;59:13-7.

7. Morrens M, Hulstijn W, Sabbe B. Psychomotor slowing in schizophrenia. Schizoph Bull. 2007;33:1038-53.

8. Dickinson D, Ramsey ME, Gold JM. Overlooking the obvious: A meta-analytic comparison of digit symbol coding tasks and other cognitive measures in schizophrenia. Arch Gen Psychiatry. 2007;64:532-42.

9. Schaefer J, Giangrande E, Weinberger DR, Dickinson D. The global cognitive impairment in schizophrenia: Consistent over decades and around the world. Schizophr Res. 2013;150:42-50.

10. Reed RA, Harrow M, Herbener ES, Martin EM. Executive function in schizophrenia: is it linked to psychosis and poor life functioning? J Ner Mentl Dis. 2002;190:725-32.

11. Bryson G, Whelahan HA, Bell M. Memory and executive function impairments in deficit syndrome schizophrenia. Psychiatry Res. 2001;102:29-37.

12. Polgár P, Réthelyi JM, Bálint S, Komlósi S, Czobor P, Bitter I. Executive function in deficit schizophrenia: What do the dimensions of the Wisconsin Card Sorting Test tell us? Schizoph Res. 2010;122:85-93.

13. Fioravanti M, Bianchi V, Cinti ME. Cognitive deficits in schizophrenia: an updated metanalysis of the scientific evidence. BMC Psychiatry. 2012;12:120.

14. Hildebrandt H, Brokate B, Eling P, Lanz M. Response shifting and inhibition, but not working memory, are impaired after long-term heavy alcohol consumption. Neuropsychology. 2004;18:20311.
15. Pitel AL, Beaunieux H, Witkowski T, Vabret F, Guillery-Girard B, Quinette P, Desgranges B, Eustache F. Genuine episodic memory deficits and executive dysfunctions in alcoholic subjects early in abstinence. Alcohol Clin Res. 2007;31:1169-78.

16. Stavro K, Pelletier J, Potvin S. Widespread and sustained cognitive deficits in alcoholism : a metaanalysis. Addict Biol. 2012;18:203-13.

17. Hammar A, Ardal G. Cognitive functioning in major depression - a summary. Frontiers in Hum Neurosci. 2009;3:1-7.

18. Rose EJ, Ebmeier KP. Pattern of impaired working memory during major depression. J Affect Disord. 2006;90:149-61.

19. Rock PL, Roiser JP, Riede WJ, Blackwell AD. Cognitive impairment in depression: a systematic review and meta-analysis. Psychol Med. 2014;44:2029-40.

20. Henry JD, Crawford JR. A meta-analytic review of verbal fluency deficits in depression. J Clin Exp Neuropsychol. 2005;27:78-101.

21. Ravnkilde B, Videbech P, Clemmensen K, Egander A, Rasmussen NA, Rosenberg R. Cognitive deficits in major depression. Scand J Psychol. 2002;43:239-51.

22. Porter RJ, Gallagher P, Thompson JM, Young AH. Neurocognitive impairment in drug - free patients with major depressive disorder. Br J Psychiatry 2003;182:214-20.

23. Gohier B, Ferracci L, Surguladze SA, Lawrence E, El Hage W, Kefi MZ, Allain P, Garre JB, Le Gall D.Cognitive inhibitionand working memory in unipolar depression. J Affect Disord. 2009;116:1005.

24. McDermott LM, Ebmeier KP. A meta-analysis of depression severity and cognitive function. J Affect Disord. 2009;119:1-8.

25. Fossati P, Amar G, Raoux N, Ergis AM, Allilaire JF. Executive functioning and verbal memory in young patients with unipolar depression and schizophrenia. Psychiatry Res. 1999;89:171-87.

26. Moritz S, Birkner C, Kloss M, Jahn H, Hand I, Haasen C, Krausz M. Executive functioning in obsessive-compulsive disorder,unipolar depression, and schizophrenia. Arch Clin Neuropsychol. 2002;17:477-83.

27. Matešić K, Karlović D. Trijažni Triage test for assessing cognitive functions in psychiatric disorders - 5-KOG. Unpublished test. 


\section{Usporedba izvedbe na 5-KOG testu u pacijenata sa shizofrenijom, alkoholizmom i depresijom}

Sažetak - Kogntivne funkcije su neophodne u normalnom funkcioniranju svakog pojedinca, a u slučaju njihovog narušenja govorimo o kognitivnom deficitu. Svaki psihijatrijski poremećaj je specifičan u smislu zahvaćenog područja i opsega kognitivnog deficita, a njihova detekcija je od velike važnosti za diferencijalnu dijagnostiku, uspješnost liječenja i oporavka, kao i društvene reintegracije pacijenata. Ova studija usporedila je rezultate dobivene 5-KOG testom, tj. istražila je različitosti rezultata podskupine testa kojima se ispituje kratkoročno i dugoročnom pamćenje, pažnja, brzina obrade informacija, radna memorija, verbalna tečnost i izvršne funkcije u kliničkim skupinama pacijenata sa shizofrenijom, alkoholizmom i depresijom. Korelacija između podskupina svake kliničke skupine pacijenata je također istražena. Ukupno 86 ispitanika koji su liječeni na Klinici za psihijatriju jedne bolnice u Zagrebu je sudjelovalo u ovom istraživanju, od toga 29 koji boluju od shizofrenije, 28 od depresije, te 29 od alkoholizma. 5-KOG trijažni test korišten je kako bi se procijenila kognitivna funkcija u pacijenata s psihijatrijskim poremećajima. Studija nije pokazala značajnu razliku u dobivenim rezultatima u podskupinama testa koje ocjenjuju neodgođeno i odgođeno prisjećanje, pažnju, brzinu obrade informacija, radnu memoriju, verbalnu tečnost i izvršne funkcije među ispitanim kliničkim skupinama pacijenata.

Ključne riječi: shizofrenija, alkoholizam, depresija, kongitivne funkcije 
